\title{
IMPROVEMENT OF THE EVALUATION METHOD OF CALCULATION OF POWER LOSSES IN POWER TRANSFORMER
}

\author{
PIDLISNIY O.S. Student of the Faculty of Electrical Engineering of the National University "Zaporizhzhia \\ Polytechnic", Zaporizhzhia, Ukraine, e-mail: opodlesny14@gmail.com; \\ LUSHCHIN S.P. Ph.D, Associate professor, Associate professor of the department of physics of the \\ National University "Zaporizhzhia Polytechnic", Zaporizhzhia, Ukraine, e-mail: \\ luschin@zntu.edu.ua;
}

Purpose. The purpose of the work is to perform analytical analysis of methods for calculating power losses of a power transformer and to improve the estimation method of calculation to increase the accuracy of calculating power losses on the example of an industrial power transformer.

Methodology. Analytical and calculation method was used to determine power losses in the power transformer.

Findings. Analysis of the main power losses of power transformers is an important task to determine the optimal conditions for their operation. Analytical analysis of transformer power loss calculation methods is carried out. The relative contribution of different types of power losses is shown. The calculation of energy losses of the power transformer TM 1000/10/0.4 is performed. The losses of active and reactive energy of the transformer are determined. The efficiency of the power transformer is calculated. A generalizing formula for determining the efficiency of the transformer is proposed.

Originality. On the basis of the analytical analysis of methods of calculation of power losses of the power transformer the estimation technique is improved and calculation of losses of active and reactive energy of the industrial power transformer TM 1000/10/0.4 is carried out. A new generalizing formula for determining the efficiency of a power transformer, which takes into account the operating time of the transformer at maximum load, is proposed.

Practical value. The estimation method for calculating the power losses of an industrial power transformer under load is improved, in which a generalizing formula for determining the efficiency of a transformer is applied. The proposed technique simplifies the calculations, reduces the estimated time to determine the operating parameters of the power transformer with the required accuracy. The proposed technique was tested on the example of the power transformer TM 1000/10/0.4. It is shown that with increasing maximum load time, the efficiency of the transformer increases and asymptotically approaches the maximum value. ciency.

Keywords: power losses; power transformer; efficiency; analytical and calculation method, transformer effi-

\section{INTRODUTION}

A transformer is a static electromagnetic device in which there are no rotating parts and, consequently, no mechanical losses. All losses in the transformer are losses of active power that occur in the magnetic system, windings and other parts of the transformer in different modes of its operation.

Today there is a reduction in industrial load, the introduction of generation through alternative (renewable) power sources, the emergence of powerful agricultural consumers of electricity. As a result, there is a need to design new or upgrade existing power networks, which must meet modern requirements for energy efficiency and reliability. This requires the application of new improved methods for calculating the parameters of power networks, one of the main elements of which are distribution power transformers. The accuracy of calculating the operating parameters of transformers will depend on the accuracy of calculating the parameters of power networks and the efficiency and reliability of their operation. Therefore, determining the optimal method for calculating the power loss of the power transformer and its adaptation to mod- ern needs in terms of accuracy and computational efficiency of its parameters is an urgent task.

This problem can be solved by improving the estimation technique for calculating the power loss of a power industrial transformer for practical engineering applications, which will increase the accuracy of calculating the operating parameters of the power unit as a component of the electrical network.

\section{II.ANALYSIS OF RECENT RESEARCHES}

Based on the analysis of works on methods of calculating power losses of power transformers, we can identify the main works of foreign [1] - [3] and domestic authors [4] - [5]. It is shown that when the transformer operates at idle or under load, in the magnetic circuit of the device, electrically insulated windings and other structural elements of the device, part of the active power of the transformer decreases. Losses are variable, so the efficiency of the devices is different and never reaches $100 \%$.

In [6] the information on the electromagnetic field of transformers and reactors, methods of calculation of parameters in the operating mode, experiments with idle 
load and short circuit, classification, measurement methods and ways to reduce additional losses are given.

In [7] the main theoretical provisions and principles for determining and analyzing electricity losses in electrical networks by the criterion of minimum cost of electricity transmission are developed. The methodology and practice of calculations of electricity losses in $6-20 \mathrm{kV}$ distribution networks are given.

In the article [8] the review of analytical and empirical methods of calculation of losses and heating of elements of a design of the power transformer equipment with oil cooling is resulted, the basic simplifying assumptions are specified.

In the article [9] the calculation of losses in structural elements of power transformers and reactors by the finite element method with boundary conditions of impedance type is carried out. A mathematical model based on the application of the finite element method is proposed, which allows to more efficiently models eddy currents and losses caused by field scattering in the tank of power transformers and reactors and elements of their structures.

In the article [10] the analytical calculation of magnetization current is applied. Analytical and numerical calculations of the magnetic field and losses, as well as computational and empirical methods for estimating temperature rise are used. For a five-rod transformer with a power of 630 MVA under the action of geomagnetic currents, increased losses and heating of structural elements on the rods of the magnetic system, reservoir and increased sound level are determined.

The article [11] presents an overview of current researches on the problem of transformer losses, especially in terms of practical engineering applications. This reveals that the problem of transformer losses remains an active area of research. The article classifies the problems of transformer losses into three main groups: losses of the tank due to the power currents of the bushings, losses in the connections of the transformer core and losses in the transformer tank.

The article [12] considers the subject of distribution transformers no-load losses and the factors that influence these losses. This paper reviews methods to correct errors in no-load loss measurement caused by excitation voltage distortion and temperature. These methods depend on the ability to separate no-load losses into its hysteresis and eddy current loss components. Accordingly, methods used to separate the no-load losses into its constituent parts are also reviewed.

The article [13] discusses the theoretical issues underlying the calculation of active, reactive power and energy losses in medium / low voltage transformers. Maintaining a balance of active and reactive power is of key importance for the flawless functioning of the power system and the receipt of high-quality electricity. Based on the parameters of transformers and data from consumers measuring active and reactive power, active and reactive power and energy losses were obtained in order to assess the efficiency of transferring active power and energy through medium / low voltage transformers.

The article [14] considers the problems of increasing the power losses of the magnetic cores of power transformers that have been operating for a long time. The degree of influence of service life and repair of power transformer cores on the increase of idle losses without idling and analytical dependence of change of dynamics in time of magnitude of power losses in cores of energy transformers of $150 \mathrm{kV}$ is found. Recommendations for refinement of calculation of power losses without load in distribution network transformers are developed.

The article [15] is devoted to the development and research of a universal mathematical model of the 0.38 $\mathrm{kV}$ electric network for calculations of power losses and electric energy on the basis of information on voltage losses in power lines.

The article [16] is devoted to the main methods of estimating additional power losses in the basic elements of power consumption and power supply systems caused by the presence of voltage and current asymmetry. An analysis of existing methods for determining additional power losses in the main elements of power supply systems is carried out. It is shown that the presence of amplitude and angular asymmetry in the network leads to an increase in additional power losses in comparison with the symmetric mode.

Today, methodological recommendations are used to determine the technological costs of electricity in transformers and transmission lines [17], which are recommended by the Ministry of Energy and Coal of Ukraine to determine the technological costs of electricity in power network elements - power transformers, transmission lines and reactors. In these guidelines, the technological costs of electricity include energy losses due to electromagnetic processes in the conductive parts of the electrical network and the cores of the devices during its transmission, as well as climatic losses and energy losses in the insulation of network elements.

The analysis of previous studies presented in the above works shows that many methods of calculating power losses of power transformers are based on analytical methods of calculation using mathematical modeling of electromagnetic processes in a power transformer. The choice for the practical engineering application of a method of calculating losses is often complicated by the cumbersomeness of mathematical calculations, which are not always justified in the conditions of industrial operation of power units. Therefore, there is a need to improve calculation methods in terms of practical engineering applications.

\section{FORMULATION OF THE WORK PURPOSE}

The purpose of the work is to perform an analytical analysis of methods for calculating power losses of the power transformer and improve the evaluation method of 
calculation to perfect the accuracy of calculating power losses on the example of an industrial transformer.

\section{PRESENTATION OF THE MAIN MATERIAL AND ANALYSIS OF THE RESULTS}

The power transformer is designed to convert and transmit electrical energy without changing its power. During the operation of the transformer, energy losses occur, which are associated with the conversion of part of the electrical energy into heat, which is heated by the device and dissipated in the surrounding space. The loss of electrical energy in the transformer consists of the main components: electrical losses in the electrical windings of the transformer, magnetic losses in the magnetic circuit and additional losses.

\subsection{Electrical losses}

Heating of the transformer coils during the passage of current causes electrical losses and reduced power. Such losses on average on the network account for $5 \%$ of the total amount of energy consumed.

When the load is applied to the transformer, the electromagnetic energy from the primary winding is transferred to the secondary coil. Electrical losses are equal to the sum of losses in the transformer windings. Electrical losses in the primary and secondary windings of the transformer are determined in proportion to the squares of the currents of both coils and their resistances [1]:

$$
\Delta P_{E L}=I_{1}^{2} r_{1}+I_{2}^{2} r_{2},
$$

where $I_{1}$ and $I_{2}$ are the load currents of the primary and secondary windings of the transformer; $r_{1}$ and $r_{2}$ are the resistances of the winding conductors.

Thus, there is a dependence of $\Delta P_{E L}$ losses on the required amount of power to the final consumer. There are fluctuations in load costs in a specific time interval, so the electrical losses in the windings are different within a day, are variable and "tied" to the load modes.

To reduce electrical losses, the windings of transformers are made mainly of copper, and the cross section of the wires of the coils is increased.

\subsection{Magnetic losses}

Magnetic losses are associated with processes in the magnetic circuit of the transformer under the action of an alternating magnetic field. The causes of losses are magnetization reversal of the transformer core due to hysteresis and eddy currents (Foucault currents).

The magnetization reversal of the transformer core due to hysteresis is due to the fact that in ferromagnets there are zones of spontaneous magnetization-domains. The magnetic moments of the core domains are characterized by a chaotic orientation, so outside the influence of the external field of magnetization, the final magnetic moment of the ferromagnet is close to zero. Under the action of a magnetic field, domains change the direction of their own magnetization in the direction of the magnetization field. As a result, the domains are reoriented, their size increases and the ferromagnet is magnetized. With each reversal cycle, some work is expended, the magnitude of which is proportional to the area of the hysteresis loop. Work contributes to the thermal heating of the core and causes additional energy consumption.

The occurrence of eddy currents (Foucault currents) in the core of the transformer occurs under the action of an alternating magnetic field, which generates an alternating eddy electric field. Eddy currents also cause heating.

The magnitude of magnetic losses is determined by the properties of the ferromagnetic material of the core and depends on the magnitude of the magnetic flux and its frequency. At a constant magnitude of the magnetic flux, the magnetic losses remain unchanged when changing the mode of the transformer operation (load change). In the nominal mode of operation, their value is the same as in the idle mode and they are determined by the idle power of the transformer.

To reduce power losses in the core, use a magnetically soft material with high magnetic permeability and low coercive force. To compensate for the action of eddy currents, the magnetic circuit is made of electrically insulated plates, and the steel is specially alloyed with silicon [3], [18] - [19].

\subsection{Additional losses}

In addition to the main losses in the coils and magnetic circuit of the transformer, there are additional losses. They occur in other steel elements of the transformer structure - in the walls of the cooling tank for heat loss, yoke beams, pressing rings. Additional losses account for up to $10 \%$ of total losses and can often be ignored.

Additional losses of active power of static electromagnetic equipment also occur as a result of asymmetry of currents, which is caused by the inclusion in the power supply system of consumers, which reduces the quality of electricity [16]. In multiphase transformers, the nature of the processes is not affected by the order of phase shift, but asymmetric loads lead to losses of active power. The asymmetry of the input voltages causes the asymmetry of the output voltages, which is due to the flow of currents in the reverse sequence.

On the basis of magnetic, electric and additional losses determine the total energy loss of the power transformer.

\subsection{Efficiency}

Efficiency is calculated as the ratio of useful energy and energy consumption [20]. The reduction of energy in the power unit consists of magnetic losses occurring in the magnetic circuit and electrical losses generated in the transformer windings. The following values are used for calculations:

- active power $P_{1}$ obtained from the power supply;

- active power $P_{2}$ transferred to the final consumer;

- electrical losses $\Delta P_{E L}$ occurring in the transformer windings; 
- magnetic losses $\Delta P_{M}$, which are formed in the core;

- additional power losses $\Delta P_{A D D}$ arising in other structural elements and components on average up to $10 \%$ of all losses.

To calculate $\Delta P_{E L}$ use the formula [21]:

$$
\Delta P_{E L}=\Delta P_{E L . N O M} \beta^{2},
$$

where $\Delta P_{E L . N O M}$ - electrical losses at nominal current of the transformer, $\beta$ - load factor. Nominal electrical losses are determined based on passport data, or experimentally based on the test results of the transformer.

The value of $\Delta P_{M}$ is calculated by the formula [21]:

$$
\Delta P_{M}=\Delta P_{H}+\Delta P_{E C},
$$

where $\Delta P_{H}$ - hysteresis losses; $\Delta P_{E C}$ - losses due to eddy currents.

The efficiency of the transformer is calculated by the formula [21]:

$$
\eta=\frac{P_{2}}{P_{1}}=\frac{P_{2}}{\left(P_{2}+\Delta P_{M}+\Delta P_{E L}\right)},
$$

where $\eta$ is assumed to be zero when the transformer is not operating, and its power is used to compensate for magnetic losses.

For a more accurate calculation of efficiency, additional energy consumption is taken into account, which occurs not in the magnetic circuit and winding, but in other elements of the power unit.

4.5. Methodical principles of calculation of energy losses of elements of electric networks

The main methodological principles for calculating energy losses of electrical network elements are developed in detail and set out in [7]. For a single network element with active resistance $R$, load losses of electricity are determined by the relationship [7]:

$$
\Delta W_{L}=3 R \int_{0}^{T} I^{2}(t) d t .
$$

The analytical function that describes the law of current change over time is often unknown, so in practice various methods are used to integrate this relationship numerically, which determine the main methodological approaches to calculating the load losses of electricity in the elements of electrical networks.

The most widely used method in practice is the method of average loads. According to this method, the load losses of electricity are determined by the formula [7]:

$$
\Delta W_{L}=3 R I_{a v}^{2} k_{F}^{2} T=\frac{W_{A}^{2}+W_{R}^{2}}{U_{a v}^{2} T} R k_{F}^{2},
$$

where $I_{a v}$ is the average value of the current, $U_{a v}$ is the average value of the voltage, $k_{F}$ is the coefficient of the form of the graph, $T$ is the calculated time period, $W_{A}$ is the active electricity, $W_{R}$ is the reactive electricity.

Electricity losses in the elements of the electrical network are determined by the results of measurements as the difference between the volumes of electrical energy calculated from the simultaneously taken readings of meters installed at the input and output elements of the electrical network. In case of technical impossibility or economic inexpediency of loss measurement, they are determined by calculation in accordance with the methodological recommendations for determining the technological costs of electricity in transformers and power lines [17]. According to this method, the losses of active and reactive energy in transformers are calculated by a formula that takes into account electrical and magnetic losses.

4.6. Calculation of energy losses in the transformer TM 1000/10/0.4

The power transformer with a nominal power of $1000 \mathrm{kVA}$ and a nominal voltage of $10 \mathrm{kV}$ is involved in the work. The initial data for calculating the energy losses in the transformer are shown in Table 1.

Table 1. Initial data

\begin{tabular}{|l|c|c|}
\hline \multicolumn{1}{|c|}{ Indicator } & Expression & Value \\
\hline Nominal power, kVA & $S_{N O M}$ & 1,000 \\
\hline $\begin{array}{l}\text { The voltage is rated } \\
\text { based on the parame- } \\
\text { ters of the network 10 / } \\
0.4, \mathrm{kV}\end{array}$ & $U_{N O M}$ & 10 \\
\hline $\begin{array}{l}\text { Transmitted active } \\
\text { electricity, kWh }\end{array}$ & $W_{A}$ & 53,954 \\
\hline $\begin{array}{l}\text { Transmitted reactive } \\
\text { electricity, kvarh }\end{array}$ & $W_{R}$ & 39,062 \\
\hline $\begin{array}{l}\text { Short-circuit } \\
\text { losses, kW }\end{array}$ & $P_{S C}$ & 10.5 \\
\hline Costs in idle mode, $\mathrm{kW}$ & $P_{0}$ & 1.4 \\
\hline $\begin{array}{l}\text { Time worked under } \\
\text { load, h }\end{array}$ & $T_{H W}$ & 1,000 \\
\hline Maximum load time, $\mathrm{h}$ & $T_{M}$ & 900 \\
\hline $\begin{array}{l}\text { Time of greatest } \\
\text { losses, h }\end{array}$ & $t$ & 100 \\
\hline Power factor & $\cos \varphi$ & 0.81 \\
\hline
\end{tabular}

The device worked for 1000 hours in operating mode, and part of the time the transformer operated at maximum load, and part of the time converted electricity with the greatest losses. We apply the method of calculating the power losses in the power transformer [22], which is based on the methodology of [7] and allows you to estimate the power losses depending on the operating modes of the transformer. The following condition is used to 
calculate the consumption of the maximum possible energy of the transformer during $T_{M}$ [22]:

$$
W_{A, M} \leq 0.9 S_{N O M} \cos \varphi \cdot T_{M} .
$$

From this value of the condition $W_{A M}$ is equal to:

$$
W_{A, M}=656,100 \mathrm{kWh} \text {. }
$$

Accordingly, the time of maximum load of $T_{M}$ is 900 $\mathrm{h}$, and the time of the largest losses $t$ will be $100 \mathrm{~h}$. The power factor is found by the formula:

$$
\cos \varphi=\frac{W_{A}}{\sqrt{W_{A}^{2}+W_{R}^{2}}}=0.81 .
$$

Constant energy losses depend on the idling costs and are [22]:

$$
\begin{gathered}
\Delta W_{0, A}=P_{0} T_{H W}=1,400 \mathrm{kWh}, \\
\Delta W_{0, R}=\Delta Q_{0} T_{H W}=20,953.2 \mathrm{kvarh},
\end{gathered}
$$

where $\Delta Q_{0}$ is losses of reactive power at idling cost:

$$
\Delta Q_{0}=\sqrt{\left(\frac{I_{0} \%}{100} S_{N O M}\right)^{2}-P_{0}^{2}}=20.953 \mathrm{kvar},
$$

where $I_{0}=2.1 \%$ is coefficient of current at idling cost.

To calculate the variable losses of active energy in the calculation period, the formula [22] is used:

$$
\Delta W_{S, A}=P_{S C} t\left(\frac{W_{A}^{2}+W_{R}^{2}}{T_{M}^{2} S_{N O M}^{2}}\right)=5.75 \mathrm{kWh},
$$

reactive energy [22]:

$$
\Delta W_{S, R}=\Delta Q_{S C} t\left(\frac{W_{A}^{2}+W_{R}^{2}}{T_{M}^{2} S_{N O M}^{2}}\right)=23.97 \mathrm{kvarh},
$$

where $\Delta Q_{S C}$ is short-circuit losses of power [22]:

$$
\Delta Q_{S C}=\sqrt{\left(\frac{U_{S C} \%}{100} S_{N O M}\right)^{2}-P_{S C}^{2}}=43.757 \mathrm{kvar}
$$

where $U_{S C}=4.5 \%$ is coefficient of short-circuit losses of voltage.

Active energy losses in the calculation period are:

$$
\Delta W_{A}=\Delta W_{0, A}+\Delta W_{S, A}=1,405.75 \mathrm{kWh} .
$$

Reactive energy losses in the calculation period are:

$$
\Delta W_{R}=\Delta W_{0, R}+\Delta W_{S, R}=20,977 \mathrm{kvarh} .
$$

So, calculation results of active and reactive energy losses in the calculation period are:

- active energy losses are 1,405.75 kWh,

- reactive energy losses are 20,977 kvarh.

General energy losses in the calculation period are:

$$
\Delta W=\Delta W_{A}+\Delta W_{R} .
$$

Converting reactive energy losses to units of $\mathrm{kWh}$ :

$$
\Delta W_{R}(\mathrm{kWh})=\Delta W_{R}(\mathrm{kWArh}) \cdot \cos \varphi=16,991.37 \mathrm{kWh} .
$$

Thus, the general energy losses in the calculation period are:

$$
\Delta W=\Delta W_{A}+\Delta W_{R}=18,397.12 \mathrm{kWh} .
$$

Then we can calculate the efficiency of the transformer by the formula:

$$
\eta=\frac{W_{A, M}-\Delta W}{W_{A, M}}=0.972
$$

Thus, the efficiency of the transformer is $\eta=97.2 \%$.

The given method of calculation allows to derive the generalized formula of dependence of efficiency on time of the maximum loading and time of the greatest losses of the transformer. The resulting formula is as follows:

$$
\eta=1-A \frac{1}{T_{M}}-B \frac{t}{T_{M}^{3}},
$$

where the coefficients $A$ and $B$ are equal to:

$$
\begin{gathered}
A=\frac{\left(P_{0}+\Delta Q_{0}\right) T_{H W}}{0.9 S_{N O M} \cdot \cos \varphi}, \\
B=\frac{\left(P_{S C}+\Delta Q_{S C}\right) \cdot\left(W_{A}^{2}+W_{R}^{2}\right)}{0.9 S_{N O M} \cdot \cos \varphi} .
\end{gathered}
$$

The numerical values of the coefficients $A$ and $B$ for the conditions of this example are equal to: $A=25.2 \mathrm{~h}$, $B=246.5 \mathrm{~h}^{2}$. Then the generalized formula for calculating the efficiency for this example will be written as follows:

$$
\eta=1-25.2 \frac{1}{T_{M}}-246.5 \frac{t}{T_{M}^{3}} .
$$

To compare the results, the efficiency was calculated according to the method of calculating electricity consumption according to the normative document of the Ministry of Energy and Coal of Ukraine "Methodological recommendations for determining the technological consumption of electricity in transformers and transmission lines" [17]. The calculation according to this method showed that for the transformer TM 1000/10/0.4 the efficiency is equal to $\eta=97.1 \%$. This result almost coincides with the value of efficiency, which was obtained by us in the applied method using a generalizing formula to determine the efficiency of the transformer TM 1000/10/0.4.

The graph of relationship of efficiency on time of the maximum loading at the set time of the greatest losses of the transformer has the following view: 


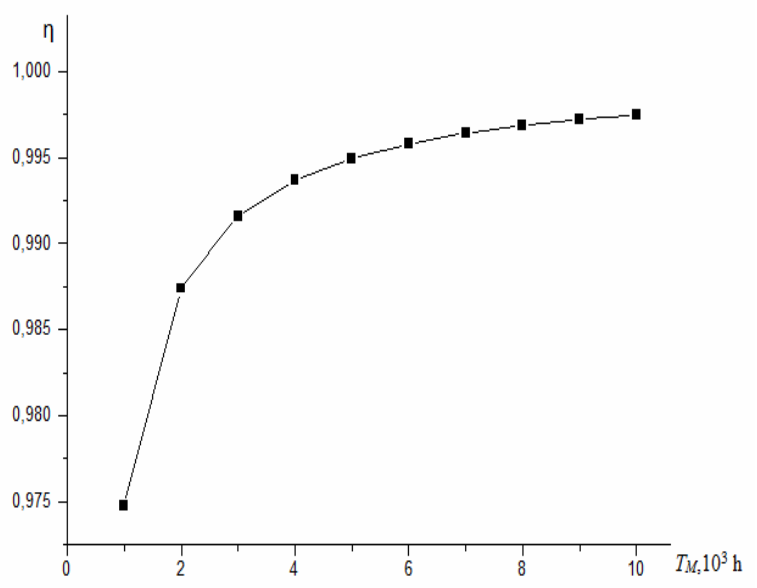

Figure 1. Graph of efficiency relationship on the time of maximum load at a given time of the largest losses of the transformer

The analysis of the obtained results allows us to state that the relationship of efficiency on the time of maximum load of the transformer at a given time of the greatest losses of the transformer has the form of a function that asymptotically approaches the maximum value with increasing $T_{M}$ value.

\section{CONCLUSIONS}

1. Analytical analysis of methods for calculating power losses in the power transformer is carried out. It is established that many methods are based on analytical calculation methods using mathematical modeling of electromagnetic processes in a power transformer. The choice for the practical engineering application of a method of calculating losses is often complicated by the cumbersomeness of mathematical calculations, which are not always justified in the conditions of industrial operation of power units.

2. Improved estimation technique for calculating power losses of the power transformer, which allows to estimate power losses depending on the operating modes of the transformer and find the value of the efficiency. A generalizing formula for determining the efficiency of the transformer is proposed. It is shown that with increasing maximum load time, the efficiency of the transformer increases and asymptotically approaches the maximum value.

3. The calculation of energy losses of the industrial power transformer TM $1000 / 10 / 0.4$ is performed. The losses of active and reactive energy of the power transformer are determined. The efficiency of the transformer at a maximum load time of 900 hours and a time of maximum losses of 100 hours is $97.2 \%$. This value of efficiency almost coincides with the efficiency obtained by the method of calculating electricity consumption according to the normative document of the Ministry of Energy and Coal of Ukraine.

\section{REFERENCES}

[1] Kulkarni S.V., Khaparde S.A. (2013). Transformer Engineering Design, Technology, and Diagnostics. CRC Press, 742.

[2] Moser H.P., Dahinden V. (1999). Transformerboard 2. Graphics DOK MAN, 222.

[3] Larin V.S. (2015). Silovye transformatory. Moskva, Znak, 391.

[4] Silovye transformatory. Spravochnaja kniga (2004)/ Pod red. S.D. Lizunova, A.K. Lohanina. M. Jenergoizdat, $616 \mathrm{~s}$

[5] Biki, M. A. (2013). Proektirovanie silovyh transformatorov. Raschety osnovnyh parametrov. M. Znak, 612.

[6] Lejtes, L. V. (1981). Jelektromagnitnye raschety transformatorov i reaktorov. M. Jenergija, 392.

[7] Fursanov M.I. (2005). Opredelenie i analiz poter' jelektrojenergii $\mathrm{v}$ jelektricheskih setjah jenergosistem. - Mn.: UVIC pri UP «Beljenergosberezhenie», 208.

[8] Ivankov, V., Basova, A., \& Shulga, N. (2014). Electric-heatings calculation models of structural elements of transformer equipment. Electrical Engineering and Power Engineering, 2, 41-53. doi:http://dx.doi.org/10.15588/1607-6761-2014-2-6

[9] Ostrenko, M., \& Tykhovod, S. (2016). Raschet poter' $\mathrm{v}$ jelementah konstrukcii silovyh transformatorov $\mathrm{i}$ reaktorov metodom konechnyh jelementov s granichnymi uslovijami impedansnogo tipa. Elektrotehnika i elektroenergetika, 2 , 33-42. doi:http://dx.doi.org/10.15588/1607-6761-2016-2-4

[10]Ivankov, V., \& Basova, A. (2019). Calculation of the geomagnetic induced currents impact on the highpower transformer. Electrical Engineering And Power Engineering, 4, 8-20. doi:http://dx.doi.org/10.15588/1607-6761-2019-4-1

[11]Juan C. Olivares-Galván, Pavlos S. Georgilakis \& Rodrigo Ocon-Valdez (2009). A Review of Transformer Losses. Electric Power Components and Systems, 37:9, 1046-1062, DOI:10.1080/15325000902918990

[12]Takach, D. S., Boggavarapu, R. L. (1985). Distribution transformer noload losses. Power Appar. Syst. IEEE Trans., 1, 181-193. DOI: 10.1109/TPAS.1985.318892

[13]Michal Kolcun, Anna Gawlak, Miroslaw Kornatka, Zsolt Čonka (2020). Active and Reactive Power Losses in Distribution Transformers. Acta Polytechnica Hungarica, 17, 1, 161-174.

[14]Krasovskiy, P. (2015). Calculation of power losses in power transformers considering the operation life. Electrification of Transport, 10, 74-80.

[15]Zorin, V., Buyniy, R., \& Perepecheniy, V. (2015). Modeli i metody rascheta i ocenki poter' moshhnosti i jelektricheskoj jenergii $\mathrm{v}$ raspredelitel'nyh setjah 0,38 $\mathrm{kV}$. Jenergosberezhenie. Jenergetika. Jenergoaudit, 5, 19-27.

[16]Ded, A.V., Parshukova, A.V., Halitov, N.A. (2015). 
Ocenka dopolnitel'nyh poter' moshhnosti ot nesimmetrii naprjazhenij i tokov v jelementah sistem jelektrosnabzhenija. Mezhdunarodnyj zhurnal prikladnyh i fundamental'nyh issledovanij,10-3, 421-425.

[17]Metodichni rekomendaciï viznachennja tehnologichnih vitrat elektrichnoï energiï $\mathrm{v}$ transformatorah $\mathrm{i}$ linijah elektroperedavannja. https://www.energy.mk.ua/index.php/77-akciarazdel/akcia-kategoria/634-metodika9.html

[18]Strnat, K.J. (1990). Modern Permanent Magnets for Application in Electro-Technology. Proceedings of the IEEE, 78, 6, 923-925. DOI: 10.1109/5.56908

[19]G. Bertotti, (1988). General properties of power losses in soft ferromagnetic materials. Magn. IEEE Trans., 24, 1, 621-630. DOI: 10.1109/20.43994
[20]Stefan Fassbinder (2013). Efficiency and Loss Evaluation of Large Power Tranformers, ECI Publication No Cu0144, Issue 01, Available from www.leonardo-energy.org

[21]Proskurjakov, V.S., Sobolev, S.V. (2009). Tehnicheskie dannye i jekspluatacionnye harakteristiki transformatora. Virtual'nyj praktikum. Uchebnoe jelektronnoe tekstovoe izdanie. Ekaterinburg, GOU VPO UGTU-UPI, 26.

[22]https://opori-osveshenia.ru/sovety/elektricheskiepoteri.html

\title{
ВДОСКОНАЛЕННЯ ОЦІНОЧНОЇ МЕТОДИКИ РОЗРАХУНКУ ВТРАТ ПОТУЖНОСТІ СИЛОВОГО ТРАНСФОРМАТОРА
}

ПІДЛІСНИЙ О.С. студент електротехнічного факультету Начіанального університету «Запорізька політехніка», Запоріжжя, Україна, е-таil: ороdlesny14@gmail.com;

\author{
ЛУЩИН С.П.
}

канд. фіз.-матем. наук, доиент кафедри фізики Національного університету «Запорізька політехніка», Запоріжжя, Україна, е-таil: luschin@zntu.edu.ua;

Мета роботи. Метою роботи є проведення аналітичного аналізу методик розрахунку втрат потужності силового трансформатора і вдосконалення оціночної методики розрахунку для підвищення точності обчислення втрат потужності на прикладі промислового силового трансформатора.

Методи дослідження. Аналітико-розрахункові методи для визначення втрат потужності силового трансформатора.

Отримані результати. Аналіз основних втрат потужності силових трансформаторів є важливим завданням для визначення оптимальних умов їх роботи. Проведено аналітичний аналіз методів розрахунку втрат потужності трансформатора. Показано відносний внесок різних типів втрат потужності. Виконано розрахунок втрат енергії силового трансформатора ТМ 1000/10/0,4. Визначено втрати активної та реактивноі енергії трансформатора. Розраховано коефіиієнт корисної дії силового трансформатора. Запропонована узагальнююча формула для визначення коефіцієнту корисної дії трансформатора.

Наукова новизна. На основі аналітичного аналізу методів розрахунку втрат потужності силового трансформатора вдосконалено оціночну методику і проведено розрахунок втрат активної та реактивної енергї̈ промислового силового трансформатора TM 1000/10/0,4. Запропоновано нову узагальнюючу формулу для визначення коефіцієнту корисної дії силового трансформатора, яка враховує час роботи трансформатора при максимальному навантаженні.

Практична чінність. Вдосконалена очіночна методика розрахунку втрат потужності промислового силового трансформатора під навантаженням, в якій застосована узагальнююча формула визначення коефіцієнта корисної дії трансформатора. Запропонована методика спрощує розрахунки, скорочує розрахунковий час визначення експлуатачійних параметрів силового трансформатора з необхідною точністю. Запропонована методика була випробувана на прикладі роботи силового трансформатора ТМ 1000/10/0,4. Показано, що при збільшенні часу максимального навантаження, коефіцієнт корисної дї трансформатора збільшується $і$ асимптотично наближсається до максимального значення.

Ключові слова: втрати потужності; силовий трансформатор; аналітично-розрахунковий метод, коефіцієнт корисної дії трансформатора.

\section{УСОВЕРШЕНСТВОВАНИЕ ОЦЕНОЧНОЙ МЕТОДИКИ РАСЧЕТА ПОТЕРЬ МОЩНОСТИ СИЛОВОГО ТРАНСФОРМАТОРА}

\author{
пидлисный \\ O.C. \\ студент электротехнического факультета Национального университета \\ «Запорожская политехника», Запорожье, Украина, e-mail: opodlesny14@gmail.com;
}


ЛУЩИН С.П. канд. физ.-матем. наук, доиент кафедры физики Национального университета «Запорожская политехника», Запорожье, Украина, e-mail: luschin@zntu.edu.ua;

Цель работы. Целью работы является проведение аналитического анализа методик расчета потерь момности силового трансформатора и усовершенствование оценочной методики расчета для повытения точности вычисления потерь мощности на примере промышленного силового трансформатора.

Методы исследования. Аналитико-расчетные методы для определения потерь мощности силового трансформатора.

Полученные результаты. Анализ потерь мощности силовых трансформаторов является важной задачей для определения оптимальных условий их работы. Проведен аналитический анализ методов расчета потерь мощности трансформатора. Показан относительный вклад различных типов потерь мощности. Выполнен расчет потерь энергии силового трансформатора ТМ 1000/10/0,4. Определены потери активной и реактивной энергии трансформатора. Рассчитан коэффициент полезного действия силового трансформатора. Предложена обобщающая формула для определения коэффиџиента полезного действия трансформатора.

Научна новизна. На основе аналитического анализа методов расчета потерь мочности силового трансформатора усовершенствована оценочная методика и проведен расчет потерь активной и реактивной энергии промыциленного силового трансформатора TM 1000/10/0,4. Предложена новая обобщающая формула для определения коэффиииента полезного действия силового трансформатора, которая учитывает время работы трансформатора при максимальной нагрузке.

Практическая ченность. Усовершенствована оченочная методика расчета потерь мочности промышленного силового трансформатора под нагрузкой, в которой применена обобщающая формула определения коэффиииента полезного действия трансформатора. Предложенная методика упрощает расчеты, сокращает расчетное время определения эксплуатационных параметров силового трансформатора с требуемой точностью. Предложенная методика была опробована на примере работы силового трансформатора ТМ 1000/10/0,4. Показано, что при увеличении времени максимальной нагрузки, коэффициент полезного действия трансформатора увеличивается и асимптотически приближсается к максимальному значению.

Ключевые слова: потери мочности; силовой трансформатор; аналитико-расчетный метод, коэффичиент полезного действия трансформатора. 